Communication

\title{
Partial oxidation of methane to syngas over mesoporous $\mathrm{Co}-\mathrm{Al}_{2} \mathrm{O}_{3}$ catalysts
}

\author{
LIU Ruiyan, YANG Meihua, HUANG Chuanjing *, WENG Weizheng, WAN Huilin \# \\ State Key Laboratory for Physical Chemistry of Solid Surfaces, Department of Chemistry, College of Chemistry and Chemical Engineering, Xiamen \\ University, Xiamen 361005, Fujian, China
}

\section{A R T I C L E I N F O}

Article history:

Received 25 September 2012

Accepted 8 November 2012

Published 20 January 2013

\section{Keywords:}

Methane

Partial oxidation

Syngas

Cobalt

Alumina

Mesopore

\section{A B S T R A C T}

Mesoporous Co- $\mathrm{Al}_{2} \mathrm{O}_{3}$ catalysts were prepared by one-pot synthesis and, for the first time, used in the partial oxidation of methane to synthesis gas. Compared with the catalysts prepared by impregnation methods, the catalysts prepared by one-pot synthesis showed superior catalytic performance for this reaction. The results showed that mesoporous $\mathrm{Co}-\mathrm{Al}_{2} \mathrm{O}_{3}$ catalysts have high surface areas, large pore volumes, and an ordered hexagonal mesostructure. In the catalysts, Co species are highly dispersed, resulting in high dispersion of the metal after reduction. A confinement effect, provided by the mesopores, on metal nanoparticles could effectively enhance resistance to metal sintering.

(C) 2013, Dalian Institute of Chemical Physics, Chinese Academy of Sciences. Published by Elsevier B.V. All rights reserved.
The partial oxidation of methane (POM) to synthesis gas (syngas) has received much attention because of its high reaction rate, low energy consumption, and syngas production with an $\mathrm{H}_{2} / \mathrm{CO}$ ratio very suitable for the synthesis of methanol and in Fischer-Tropsch syntheses. Among the catalysts reported for the POM reaction, Ni- and Co-based catalysts are particularly promising because of their low prices. Compared to Ni-based catalysts, Co-based catalysts show higher resistance to carbon deposition, but lower activities [1-3]; Co-based catalysts have therefore received less attention. Previous results [4-6] revealed that the catalytic performances of Co-based catalysts are closely related to the dispersion and anti-sintering ability of Co, which depend largely on the nature of the support and catalyst preparation.

Alumina is an important support in catalysis, and alumi- na-supported Co catalysts have wide applications in Fischer-Tropsch syntheses [7-9]. In recent papers [6,10], it has been reported that these catalysts provide good catalytic performances in POM reactions. Mesoporous materials have high surface areas, large pore volumes, and narrow pore size distributions. These features make mesoporous materials good carriers for highly dispersed metal loadings, and the confinement effect of the mesopores can prevent the metal particles from sintering. Mesoporous alumina-supported Co catalysts can therefore be expected to show enhanced catalytic performances. Recently, a facile and reproducible preparation method for ordered mesoporous alumina (OMA) was reported by Yuan et al. [11]. This was extended by Morris et al. [12] to the one-pot synthesis of OMA-supported metal oxides ( $\mathrm{NiO}, \mathrm{MgO}, \mathrm{CaO}$, $\mathrm{TiO}_{2}$ ). In this work, a similar preparation procedure was used

\footnotetext{
* Corresponding author. Tel: +86-592-2188087; Fax: +86-592-2183047; E-mail: huangcj@xmu.edu.cn \# Corresponding author. Tel: +86-592-2186569; Fax: +86-592-2183047; E-mail: hlwan@xmu.edu.cn

This work was supported by the National Basic Research Program of China (973 Program, 2010CB732303), the National Natural Science Foundation of China (21173173, 21073148, 21033006), the Program for Innovative Research Team of the Ministry of Education of China (IRT1036), and the Key Scientific Project of Fujian Province, China (2009HZ0002-1). DOI: $10.1016 / S 1872-2067(11) 60481-6$
} 
to synthesize mesoporous $\mathrm{Co}-\mathrm{Al}_{2} \mathrm{O}_{3}$ catalysts, and the results of POM reactions over these catalysts were reported for the first time.

Mesoporous alumina (meso- $\mathrm{Al}_{2} \mathrm{O}_{3}$ ) was synthesized using the procedure reported by Yuan and co-workers [11], and the as-synthesized meso- $\mathrm{Al}_{2} \mathrm{O}_{3}$ was calcined at $700{ }^{\circ} \mathrm{C}$. The procedure was modified and extended to the one-pot synthesis of meso- $\mathrm{Al}_{2} \mathrm{O}_{3}$-supported Co (Co-meso- $\mathrm{Al}_{2} \mathrm{O}_{3}$ ) catalysts. Typically, $4.5 \mathrm{~g}$ of Pluronic P123 were dissolved in $100 \mathrm{ml}$ of anhydrous ethanol, and $7.5 \mathrm{ml}$ of $65 \% \mathrm{HNO}_{3}$ and $10.2 \mathrm{~g}$ of aluminum isopropoxide were added to the P123 solution under stirring. The Co precursor, $\mathrm{Co}\left(\mathrm{NO}_{3}\right)_{2} \cdot 6 \mathrm{H}_{2} \mathrm{O}$, was then dissolved in the above solution with vigorous stirring for $5 \mathrm{~h}$. The solvent was evaporated at $60^{\circ} \mathrm{C}$ for $48 \mathrm{~h}$ in an oven. The resulting samples were calcined at $400{ }^{\circ} \mathrm{C}$ for $4 \mathrm{~h}$ and at $700{ }^{\circ} \mathrm{C}$ for $1 \mathrm{~h}$. For comparison, meso- $\mathrm{Al}_{2} \mathrm{O}_{3}$ - and commercial- $\gamma-\mathrm{Al}_{2} \mathrm{O}_{3}$-sup- ported Co catalysts were also prepared using an impregnation method. These are denoted by $\mathrm{Co} /$ meso- $\mathrm{Al}_{2} \mathrm{O}_{3}$ and $\mathrm{Co} / \gamma-\mathrm{Al}_{2} \mathrm{O}_{3}$, respectively. Briefly, the supports were impregnated with an aqueous solution of $\mathrm{Co}\left(\mathrm{NO}_{3}\right)_{2} \cdot 6 \mathrm{H}_{2} \mathrm{O}$, followed by drying and the same calcining procedures as those used for the Co-meso- $\mathrm{Al}_{2} \mathrm{O}_{3}$ catalysts. Unless stated, the amount of Co was fixed at $9 \mathrm{wt} \%$ in all the catalysts in this study.

The catalytic reaction was carried out in a fixed-bed vertical quartz-reactor (i.d. $=5 \mathrm{~mm}$ ) under atmospheric pressure. Prior to reaction, the catalyst was reduced at $700{ }^{\circ} \mathrm{C}$ in an $\mathrm{H}_{2}$ flow $(30$ $\mathrm{ml} / \mathrm{min}$ ) for $\mathrm{l} \mathrm{h}$, followed by Ar purging and heating under an Ar flow to the reaction temperature $\left(750^{\circ} \mathrm{C}\right)$. The feed gas, of molar composition $\mathrm{CH}_{4}: \mathrm{O}_{2}: \mathrm{Ar}=2: 1: 4$, was passed through the reactor at a space velocity of $1 \times 10^{5} \mathrm{ml} /(\mathrm{g} \cdot \mathrm{h})$. After condensing and drying, the reaction effluents were analyzed using an
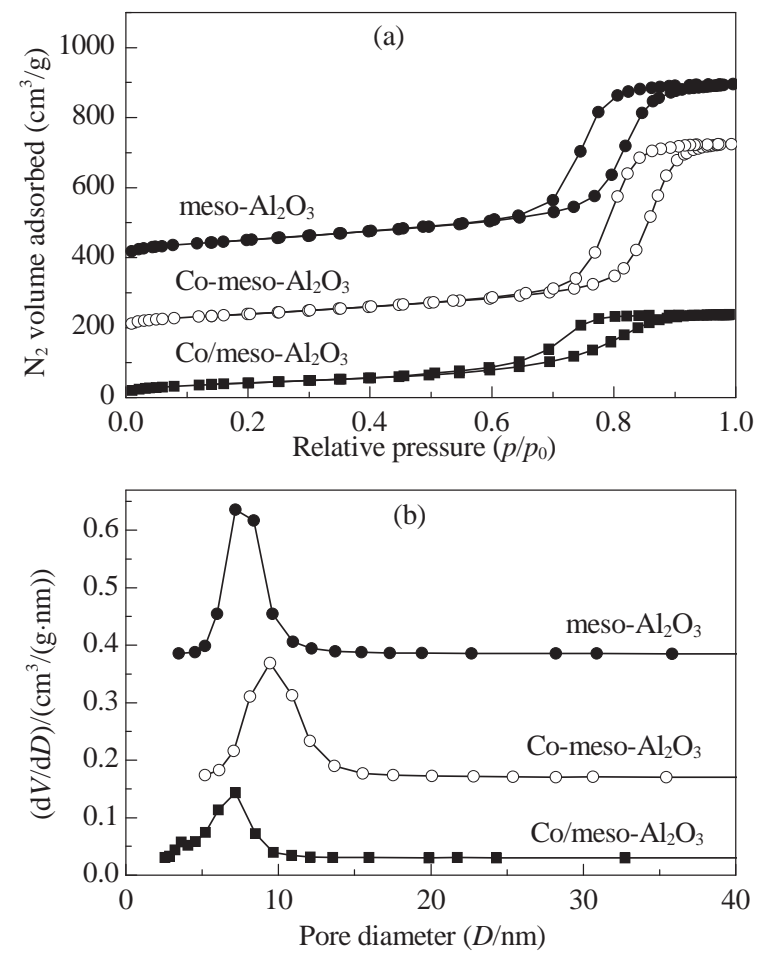

Fig. 1. $\mathrm{N}_{2}$ adsorption-desorption isotherms (a) and BJH pore diameter distribution (b) of various catalysts.
Table 1

Surface areas and pore structures of different catalysts.

\begin{tabular}{lccc}
\hline Catalyst & $\begin{array}{c}A \text { BET } \\
\left(\mathrm{m}^{2} / \mathrm{g}\right)\end{array}$ & $\begin{array}{c}\text { Pore volume } \\
\left(\mathrm{cm}^{3} / \mathrm{g}\right)\end{array}$ & $\begin{array}{c}\text { Average pore } \\
\text { size }(\mathrm{nm})\end{array}$ \\
\hline$\gamma-\mathrm{Al}_{2} \mathrm{O}_{3}$ & 173.9 & - & - \\
$\mathrm{meso}^{-} \mathrm{Al}_{2} \mathrm{O}_{3}$ & 294.2 & 0.84 & 8.0 \\
$\mathrm{Co}-\mathrm{meso}-\mathrm{Al}_{2} \mathrm{O}_{3}$ & 241.2 & 0.83 & 9.3 \\
$\mathrm{Co} / \mathrm{meso}^{-} \mathrm{Al}_{2} \mathrm{O}_{3}$ & 178.2 & 0.38 & 6.4 \\
$\mathrm{Co} / \gamma-\mathrm{Al}_{2} \mathrm{O}_{3}$ & 126.4 & 0.30 & 6.9 \\
\hline
\end{tabular}

on-line gas chromatograph equipped with a thermal conductivity detector and a TDX-01 column.

The results of $\mathrm{N}_{2}$ adsorption-desorption isotherm measurements are shown in Fig. 1 and Table 1. As shown in Fig. 1, both meso- $\mathrm{Al}_{2} \mathrm{O}_{3}$ and Co-meso- $\mathrm{Al}_{2} \mathrm{O}_{3}$ present a typical type-IV isotherm with a steep H1-shaped hysteresis loop, suggesting uniform cylindrical pores [11]. In contrast, $\mathrm{Co} / \mathrm{meso}-\mathrm{Al}_{2} \mathrm{O}_{3}$ shows a broad capillary condensation step, revealing a significant change in the pore structure. The pore-filling step of the $\mathrm{Co} / \mathrm{meso}^{-} \mathrm{Al}_{2} \mathrm{O}_{3}$ catalyst shifts to a lower relative pressure, which indicates a decrease in mesopore size, and is consistent with the Barrett-Joyner-Halenda (BJH) pore diameter distribution. As shown in Table 1, Co-meso- $\mathrm{Al}_{2} \mathrm{O}_{3}$ has the highest surface area and the largest pore volume among the catalysts studied. All the catalysts show the expected decreases in surface area and pore volume as a result of the introduction of Co species into the alumina. However, the decreases are more pronounced for the samples prepared by impregnation, indicating that the support pores are largely blocked by the Co species.

Figure 2 shows the X-ray diffraction (XRD) patterns of various samples. As shown in Fig. 2(a), the meso- $\mathrm{Al}_{2} \mathrm{O}_{3}$ and Co-meso- $\mathrm{Al}_{2} \mathrm{O}_{3}$ samples present similar small-angle XRD patterns. A strong and a weak peak, ascribed to the (100) and (110) planes, respectively, appear at $2 \theta=0.8^{\circ}$ and $1.5^{\circ}$, indicating that the samples have an ordered hexagonal mesostructure. For the $\mathrm{Co} / \mathrm{meso}_{-} \mathrm{Al}_{2} \mathrm{O}_{3}$ catalyst, however, the small-angle diffraction peaks disappear completely, revealing that the carrier mesostructure was destroyed during preparation of the catalyst. This is in agreement with the $\mathrm{N}_{2}$ adsorption-desorption results. As shown in Fig. 2(b), the $\mathrm{Co} / \gamma-\mathrm{Al}_{2} \mathrm{O}_{3}$ and $\mathrm{Co} /$ meso- $\mathrm{Al}_{2} \mathrm{O}_{3}$ catalysts prepared by impregnation both show strong XRD peaks assignable to $\mathrm{Co}_{3} \mathrm{O}_{4}$ and/or $\mathrm{CoAl}_{2} \mathrm{O}_{4}$, whereas no Co-containing phase could be observed for the Co-meso- $\mathrm{Al}_{2} \mathrm{O}_{3}$ catalyst. This demonstrates that the Co species are highly dispersed in the latter sample. Figure 2(b) also shows the XRD patterns of the catalysts after reduction in $\mathrm{H}_{2}$ at $800{ }^{\circ} \mathrm{C}$ for $2 \mathrm{~h}$. All the reduced catalysts display diffraction peaks assigned to metallic $\mathrm{Co}$, but the peak in Co-meso- $\mathrm{Al}_{2} \mathrm{O}_{3}$ is much weaker and broader, indicating that this catalyst has smaller Co particles. This result was further confirmed by transmission electron microscopy (TEM) observations.

Figure 3 shows the TEM images of the catalysts after reduction and the energy-dispersive X-ray (EDX) spectrum of Co-meso- $\mathrm{Al}_{2} \mathrm{O}_{3}$, collected from the TEM image region. Large metal particles are clearly observed on both the $\mathrm{Co} / \gamma-\mathrm{Al}_{2} \mathrm{O}_{3}$ and $\mathrm{Co} /$ meso- $\mathrm{Al}_{2} \mathrm{O}_{3}$ catalysts, showing that Co aggregation occurred 

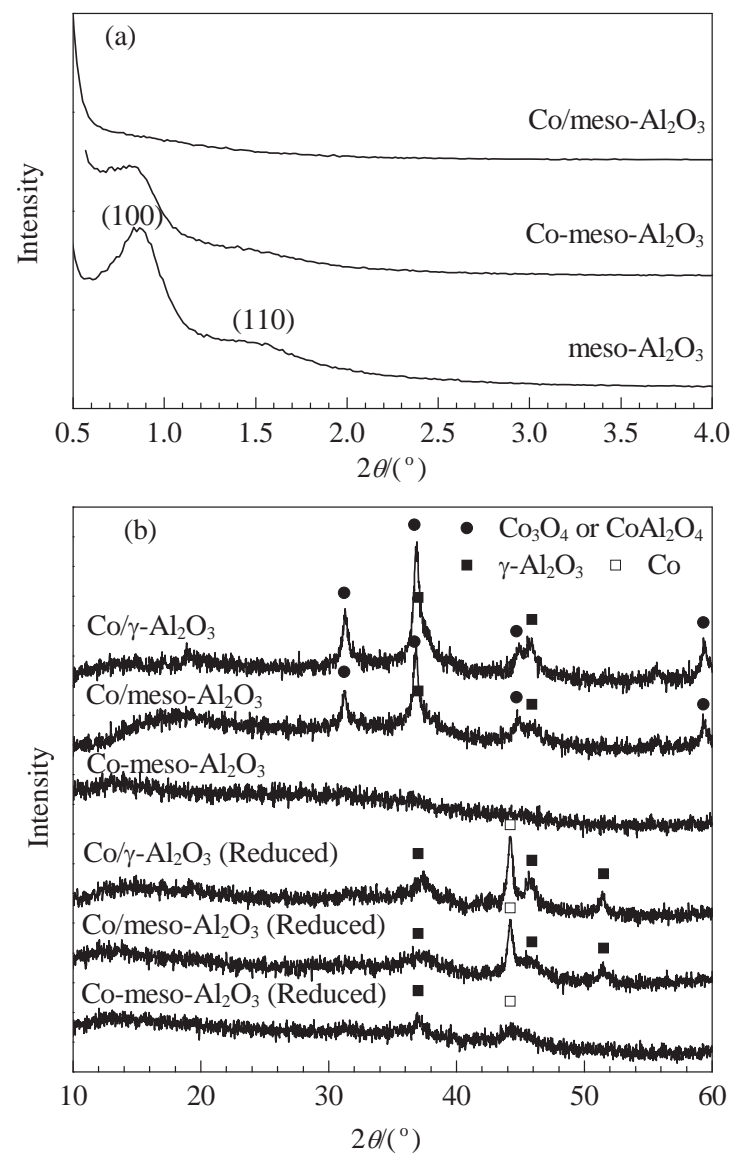

Fig. 2. Small-angle (a) and wide-angle (b) XRD patterns of various catalysts.

during the high-temperature reduction. For the Co-meso- $\mathrm{Al}_{2} \mathrm{O}_{3}$ catalyst, the ordered hexagonal channels were unaffected by reduction at a high temperature of $800{ }^{\circ} \mathrm{C}$. No aggregated particles were found on this catalyst, but a strong Co signal was detected in the EDX spectrum. From the XRD results shown in Fig. 2(b), and the TEM and EDX results, it can be concluded that Co metal is highly dispersed in the channels of the host alumina as nanosized particles.

The temperature-programmed reduction $\left(\mathrm{H}_{2}\right.$-TPR) profiles of various catalysts are shown in Fig. 4 . On $\mathrm{Co} / \gamma-\mathrm{Al}_{2} \mathrm{O}_{3}$, two peaks appear, at 520 and $730{ }^{\circ} \mathrm{C}$, which can be assigned to the

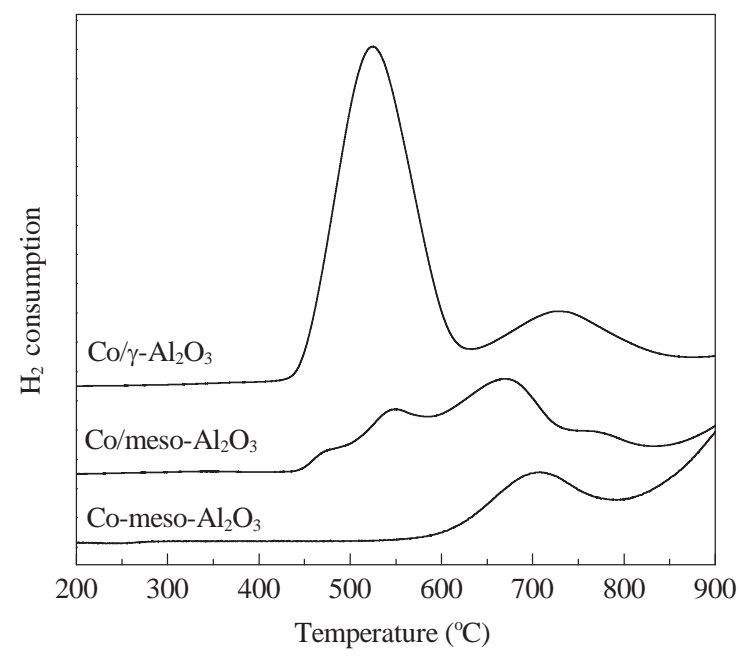

Fig. 4. $\mathrm{H}_{2}$-TPR profiles of various catalysts.

reduction of $\mathrm{Co}_{3} \mathrm{O}_{4}$ and of surface Co oxides that interact more strongly with the support, respectively $[13,14]$. The former peak is larger, indicating poor dispersion of Co species, which exist mainly as crystalline $\mathrm{Co}_{3} \mathrm{O}_{4}$ in this catalyst. The $\mathrm{Co} / \mathrm{meso}-\mathrm{Al}_{2} \mathrm{O}_{3}$ and Co-meso- $\mathrm{Al}_{2} \mathrm{O}_{3}$ catalysts both present a high-temperature peak at temperatures above $800{ }^{\circ} \mathrm{C}$, ascribed to the reduction of $\mathrm{CoAl}_{2} \mathrm{O}_{4}$ [13]. In the temperature range from 450 to $800{ }^{\circ} \mathrm{C}$, several peaks are also observed for the $\mathrm{Co} / \mathrm{meso}-\mathrm{Al}_{2} \mathrm{O}_{3}$ catalyst, revealing that $\mathrm{Co}$ species are present in many forms, including $\mathrm{Co}_{3} \mathrm{O}_{4}$ and surface Co oxides, as well as $\mathrm{CoAl}_{2} \mathrm{O}_{4}$. For Co-meso- $\mathrm{Al}_{2} \mathrm{O}_{3}$, however, only one peak, from the reduction of highly dispersed surface Co oxides, can be found, at around $700{ }^{\circ} \mathrm{C}$, indicating a higher dispersion of Co species in this sample than in the $\mathrm{Co} / \gamma-\mathrm{Al}_{2} \mathrm{O}_{3}$ and $\mathrm{Co} /$ meso- $\mathrm{Al}_{2} \mathrm{O}_{3}$ catalysts. This is consistent with the XRD results.

Figure 5 shows the catalytic performances of the catalysts. Figure 5(a) shows that the catalysts prepared by impregnation give very low $\mathrm{CH}_{4}$ conversions for a wide range of Co loadings, from 3 to 9 wt $\%$. In contrast, the Co-meso- $\mathrm{Al}_{2} \mathrm{O}_{3}$ catalysts are highly active for $\mathrm{CH}_{4}$ conversion, even at a Co content as low as $6 \mathrm{wt} \%$, indicating that a lower Co loading on these catalysts can provide a high catalytic performance. $\mathrm{Co} / \mathrm{Al}_{2} \mathrm{O}_{3}$ catalysts were reported by Wang et al. [10] to be active for POM reactions, but their Co loadings were as high as $24 \mathrm{wt} \%$. Generally, a higher
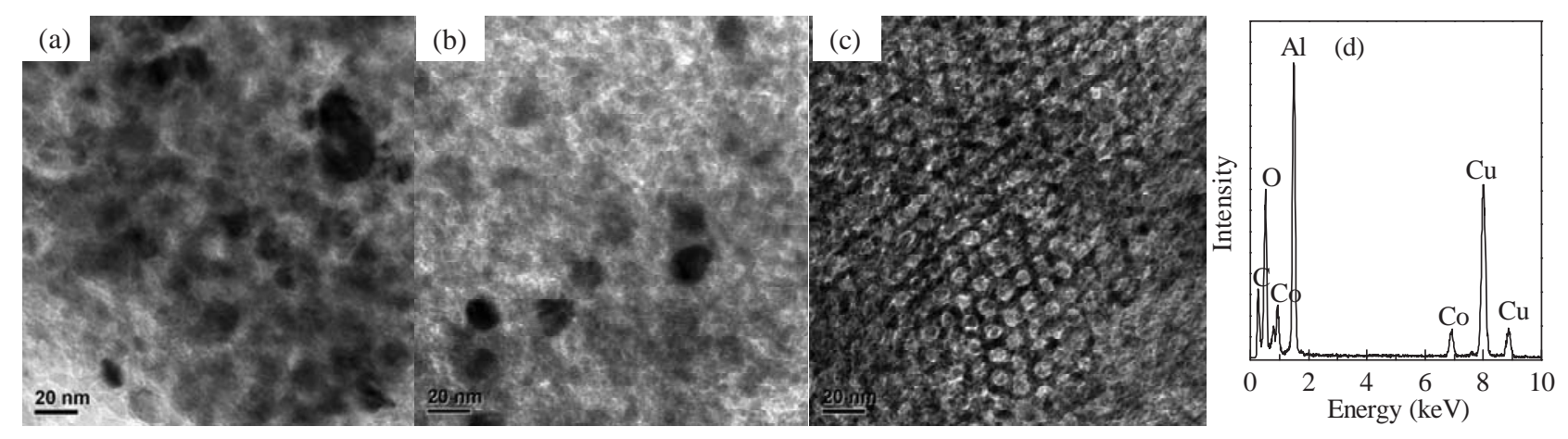

Fig. 3. TEM images of $\mathrm{Co} / \gamma-\mathrm{Al}_{2} \mathrm{O}_{3}$ (a), Co/meso- $\mathrm{Al}_{2} \mathrm{O}_{3}$ (b), and Co-meso- $\mathrm{Al}_{2} \mathrm{O}_{3}$ (c) catalysts after reduction in $\mathrm{H}_{2}$ at $800{ }^{\circ} \mathrm{C}$ for $2 \mathrm{~h}$, and $\mathrm{EDX}$ spectrum (d) of the reduced $\mathrm{Co}-\mathrm{meso}-\mathrm{Al}_{2} \mathrm{O}_{3}$ catalyst collected from the TEM image region. 

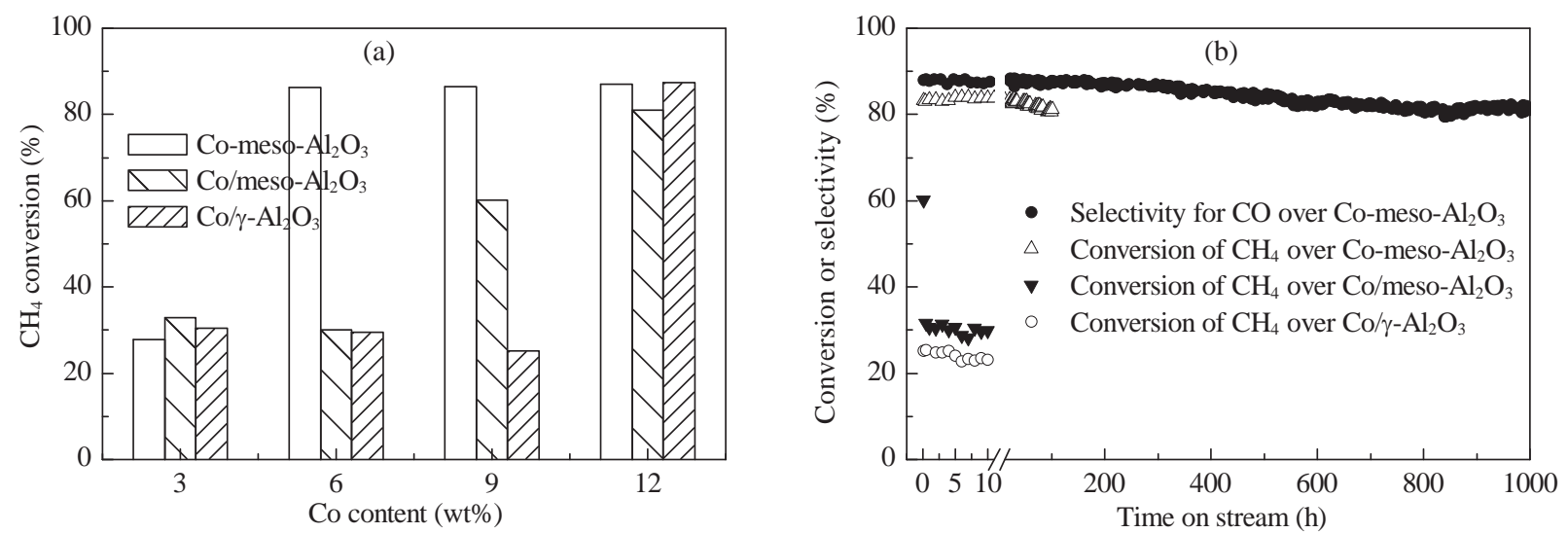

Fig. 5. Effect of Co loading on catalytic activity of different catalysts for $\mathrm{POM}$ reaction (a) and catalyst stability (b). Reaction conditions: $\mathrm{CH}_{4}: \mathrm{O}_{2}: \mathrm{Ar}=$ 2:1:4 (molar ratio), gas hourly space velocity $=1 \times 10^{5} \mathrm{ml} /(\mathrm{g} \cdot \mathrm{h}), 750{ }^{\circ} \mathrm{C}$.

metal loading tends to result in increased carbon deposition. Efficient Co catalysts with low metal loadings are therefore desirable. Figure 5(b) shows the changes in $\mathrm{CH}_{4}$ conversion and CO selectivity over different catalysts ( $9 \mathrm{wt} \% \mathrm{Co}$ ) as a function of time on stream. Compared with $\mathrm{Co} /$ meso- $\mathrm{Al}_{2} \mathrm{O}_{3}$ and $\mathrm{Co} / \gamma-\mathrm{Al}_{2} \mathrm{O}_{3}$, Co-meso- $\mathrm{Al}_{2} \mathrm{O}_{3}$ exhibited not only higher activity but also good stability. Co-meso- $\mathrm{Al}_{2} \mathrm{O}_{3}$ showed high $\mathrm{CH}_{4}$ conversion and high $\mathrm{CO}$ selectivity, without significant loss of activity and selectivity, even after a long running time of $1000 \mathrm{~h}$.

The results of this study show that mesoporous-aluminasupported Co catalysts can be directly synthesized using a one-pot synthesis. Compared with commercial $\gamma-\mathrm{Al}_{2} \mathrm{O}_{3}$ - and mesoporous alumina-supported Co samples prepared by impregnation, the samples prepared using the one-pot synthesis show distinctive structures and catalytic behaviors. For the latter samples, the high surface area and large pores enable high dispersion of the metallic Co, and the confinement effect of the mesopores effectively suppresses metal sintering under the reaction conditions used. It is therefore assumed that the high activities and better stabilities in POM reactions of the Co-meso- $\mathrm{Al}_{2} \mathrm{O}_{3}$ catalysts prepared using one-pot synthesis are closely related to their high metal dispersion and strong resistance to metal sintering, respectively.

\section{References}

[1] Choudhary V R, Rajput A M, Prabhakar B, Mamman A S. Fuel, 1998, 77: 1803

[2] Nishimoto H A, Nakagawa K, Ikenaga N O, Nishitani-Gamo M, Ando T, Suzuki T. Appl Catal A, 2004, 264: 65

[3] York A P E, Xiao T C, Green M L H. Top Catal, 2003, 22: 345

[4] Gao X X, Huang Ch J, Zhang N W, Li J H, Weng W Zh, Wan H L. Catal Today, 2008, 131: 211

[5] Zhang N W, Huang Ch J, Kuang F P, Gao X X, Weng W Zh, Wan H L. Acta Phys-Chin Sin (张诺伟, 黄传敬, 匡飞平, 高晓晓, 翁维正, 万 惠霖. 物理化学学报), 2008, 24: 2165

[6] Zhang N W, Huang Ch J, Zhu X Q, Xu J D, Weng W Zh, Wan H L. Chem Asian J, 2012, 7: 1895

[7] Iglesia, E. Appl Catal A, 1997, 161: 59

[8] Iglesia E, Soled S L, Fiato R A, Via G H.J Catal, 1993, 143: 345

[9] Khodakov A Y, Chu W, Fongarland P. Chem Rev, 2007, 107: 1692

[10] Wang H Y, Ruckenstein E. Catal Lett, 2001, 75: 13

[11] Yuan Q, Yin A X, Luo Ch, Sun L D, Zhang Y W, Duan W T, Liu H Ch, Yan Ch H. J Am Chem Soc, 2008, 130: 3465

[12] Morris S M, Fulvio P F, Jaroniec M. J Am Chem Soc, 2008, 130: 15210

[13] Arnoldy P, Moulijn J A.J Catal, 1985, 93: 38

[14] Tung H C, Yeh C T, Hong C T.J Catal, 1990, 122: 211

\section{Graphical Abstract}

Chin. J. Catal., 2013, 34: 146-151 doi: 10.1016/S1872-2067(11)60481-6

\section{Partial oxidation of methane to syngas over mesoporous} Co- $-\mathrm{Al}_{2} \mathrm{O}_{3}$ catalysts

LIU Ruiyan, YANG Meihua, HUANG Chuanjing*, WENG Weizheng, WAN Huilin*

Xiamen University

A mesoporous $\mathrm{Co}-\mathrm{Al}_{2} \mathrm{O}_{3}$ catalyst, prepared using one-pot synthesis, showed an ordered hexagonal mesostructure, high dispersion of Co species, and excellent catalytic performance for partial oxidation of methane to synthesis gas.

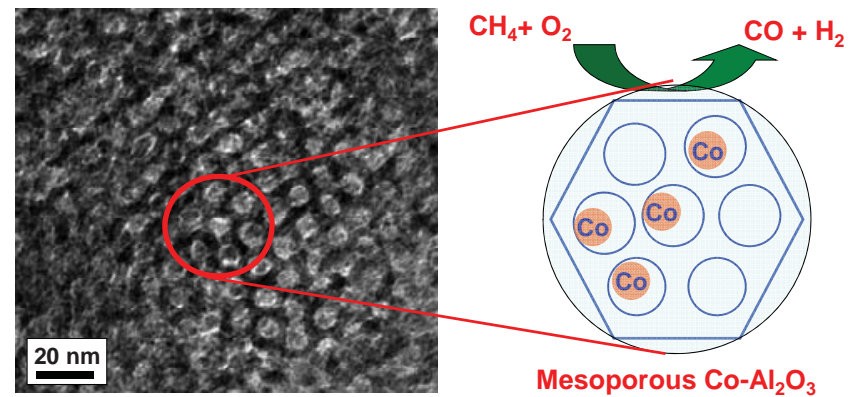




\title{
介孔 $\mathrm{Co}-\mathrm{Al}_{2} \mathrm{O}_{3}$ 催化剂上甲烷部分氧化制合成气
}

\author{
刘瑞艳, 杨美华, 黄传敬*, 翁维正, 万惠霖 ${ }^{*}$ \\ 厦门大学化学化工学院化学系, 固体表面物理化学国家重点实验室, 福建厦门 361005
}

\begin{abstract}
摘要: 采用一锅法制备了介孔 $\mathrm{Co}-\mathrm{Al}_{2} \mathrm{O}_{3}$ 催化剂, 并首次用于甲烷部分氧化制合成气反应. 结果表明,与普通浸渍法相比,一锅法制 备的 $\mathrm{Co}-\mathrm{Al}_{2} \mathrm{O}_{3}$ 催化剂表现出更为优异的催化性能. 合成的介孔 $\mathrm{Co}-\mathrm{Al}_{2} \mathrm{O}_{3}$ 催化剂具有大的比表面积和孔体积, 以及规整有序的六 方介孔孔道, Co 物种高度分散, 从而导致还原后高的金属分散度, 而介孔孔道对金属纳米颗粒的约束作用可有效增强金属的抗烧 结能力.
\end{abstract}

关键词: 甲烷; 部分氧化; 合成气; 钴; 氧化铝; 介孔

收稿日期: 2012-09-25. 接受日期: 2012-11-08. 出版日期: 2013-01-20.

*通讯联系人. 电话: (0592)2188087; 传真: (0592)2183047; 电子信箱: huangcj@xmu.edu.cn

\#通讯联系人. 电话: (0592)2186569; 传真: (0592)2183047; 电子信箱: hlwan@xmu.edu.cn

基金来源: 国家重点基础研究发展计划 (973计划, 2010CB732303); 国家自然科学基金(21173173, 21073148, 21033006); 教育部创 新团队项目 (IRT1036); 福建省重大科技专项 (2009HZ0002-1).

本文的英文电子版由Elsevier出版社在ScienceDirect上出版(http://www.sciencedirect.com/science/journal/18722067).

甲烷部分氧化 $(\mathrm{POM})$ 制合成气因具有高反应速率、 低能耗以及产物 $\mathrm{H}_{2} / \mathrm{CO}$ 比很适合甲醇合成和费托合成 等优点而受到极大关注. 在报道的 POM 反应催化剂中, 考虑到价格因素, 最具有应用前景的是 $\mathrm{Ni}$ 基和 $\mathrm{Co}$ 基催 化剂. 比较而言, Co 基催化剂具有较好的抗积炭性能,但 催化活性较低 ${ }^{[1 \sim 3]}$, 因而研究相对较少. 前期研究表明, Co 基催化剂的催化性能与 $\mathrm{Co}$ 分散度及其抗烧结能力密 切相关, 而后者极大地取决于载体的性质以及催化剂的 制备方法 ${ }^{[4 \sim 6]}$.

$\mathrm{Al}_{2} \mathrm{O}_{3}$ 是一种重要的催化剂载体, 它负载的 $\mathrm{Co}$ 催化 剂广泛应用于费托合成中 ${ }^{[7 \sim 9]}$. 最近研究表明 ${ }^{[6,10]}$, 该类 催化剂也表现出较好的催化 POM 反应性能. 介孔材料 的比表面积高, 孔体积大, 且孔径分布窄, 有利于负载于 其上的金属活性组分的高度分散. 另外, 介孔材料的孔 道限域作用可抑制反应过程中金属的烧结. 因此, 介孔 $\mathrm{Al}_{2} \mathrm{O}_{3}$ 负载的金属催化剂可望表现出较好的催化性能. Yuan 等 ${ }^{[11}$ 报道了一种制备有序介孔 $\mathrm{Al}_{2} \mathrm{O}_{3}$ 的方法, 简便 且重复性好. Morris 等 ${ }^{[12]}$ 采用该法一锅合成了介孔 $\mathrm{Al}_{2} \mathrm{O}_{3}$ 负载金属氧化物 $\left(\mathrm{NiO}, \mathrm{MgO}, \mathrm{CaO}, \mathrm{TiO}_{2}\right)$. 本文采用 类似方法成功制备了介孔 $\mathrm{Co}-\mathrm{Al}_{2} \mathrm{O}_{3}$ 催化剂, 并首次用于 POM 反应中.

参照文献[11]制备介孔氧化铝 (meso- $\mathrm{Al}_{2} \mathrm{O}_{3}$ ), 其最终 焙烧温度为 $700{ }^{\circ} \mathrm{C}$. 将上述方法加以改进, 用于 meso- $\mathrm{Al}_{2} \mathrm{O}_{3}$ 负载 $\mathrm{Co}$ 催化剂 (Co-meso- $\left.\mathrm{Al}_{2} \mathrm{O}_{3}\right)$ 的一锅合成. 将 $4.5 \mathrm{~g} \mathrm{P} 123$ 溶于 $100 \mathrm{ml}$ 无水乙醇中, 搅拌加入 $7.5 \mathrm{ml}$ $65 \%$ 的硝酸和 $10.2 \mathrm{~g}$ 异丙醇铝. 制成溶液后, 加入 $\mathrm{Co}\left(\mathrm{NO}_{3}\right)_{2} \cdot 6 \mathrm{H}_{2} \mathrm{O}$ 激烈摚拌 $5 \mathrm{~h}$. 于 $60^{\circ} \mathrm{C}$ 蒸发溶剂 $48 \mathrm{~h}$ 后, 所得样品于 $400^{\circ} \mathrm{C}$ 焙烧 $4 \mathrm{~h}$, 最后再于 $700^{\circ} \mathrm{C}$ 焙烧 $1 \mathrm{~h}$. 为
了比较, 采用浸渍法分别制备了 $\mathrm{meso}-\mathrm{Al}_{2} \mathrm{O}_{3}$ 和商品 $\gamma-\mathrm{Al}_{2} \mathrm{O}_{3}$ 负载 $\mathrm{Co}$ 催化剂, 分别记为 $\mathrm{Co} / \mathrm{meso}-\mathrm{Al}_{2} \mathrm{O}_{3}$ 和 $\mathrm{Co} / \gamma-\mathrm{Al}_{2} \mathrm{O}_{3}$. 将载体浸渍于 $\mathrm{Co}\left(\mathrm{NO}_{3}\right)_{2} \cdot 6 \mathrm{H}_{2} \mathrm{O}$ 水溶液中, 随 后经干燥和焙烧 (同 Co-meso- $\mathrm{Al}_{2} \mathrm{O}_{3}$ ) 最后制得催化剂. 除非说明, 本文所有催化剂中 Co 含量均为 $9 \%$.

$\mathrm{POM}$ 反应在常压、固定床直立石英反应器 (内径为 $5 \mathrm{~mm})$ 中进行. 反应前, 催化剂在 $\mathrm{H}_{2}(30 \mathrm{ml} / \mathrm{min})$ 中于 700 ${ }^{\circ} \mathrm{C}$ 还原 $1 \mathrm{~h}$. 随后经 $\mathrm{Ar}$ 气吹扫, 并升至反应温度 $\left(750^{\circ} \mathrm{C}\right)$. 进气切换为 $\mathrm{CH}_{4}: \mathrm{O}_{2}: \mathrm{Ar}=2: 1: 4$ (摩尔比), 空速为 $1 \times 10^{5}$ $\mathrm{ml} /(\mathrm{g} \cdot \mathrm{h})$. 反应尾气经冷凝除水后, 采用气相色谱仪 (TDX-01柱, TCD 检测器) 在线检测.

各样品的 $\mathrm{N}_{2}$ 吸附-脱附测定结果示于图 1 和表 1 . 由 图 1 可见, meso- $\mathrm{Al}_{2} \mathrm{O}_{3}$ 和 Co-meso- $\mathrm{Al}_{2} \mathrm{O}_{3}$ 催化剂的吸附等 温线均为典型的IV型, 并带有陡峭的 $\mathrm{H} 1$ 滞后回环, 表明 它们均具有较为有序的圆筒状介孔结构 ${ }^{[11]}$; $\mathrm{Co} / \mathrm{meso}^{-} \mathrm{Al}_{2} \mathrm{O}_{3}$ 催化剂的滞后环变得扁平, 说明其孔结构 发生很大变化, 其滞后环起始相对压力 $p / p_{0}$ 值较低, 意味 着孔径减小, 与孔径分布曲线相一致. 由表 1 可见, Co-meso- $\mathrm{Al}_{2} \mathrm{O}_{3}$ 催化剂具有最大的比表面积和孔体积. 金属的负载均使相应载体的比表面积和孔体积降低, 尤 其是浸渍法制备的催化剂降低的最为显著, 说明其载体 的孔道被 $\mathrm{Co}$ 物种严重堵塞.

图 2 为不同样品的 XRD 谱. 由图可见, Co-meso- $\mathrm{Al}_{2} \mathrm{O}_{3}$ 和 meso- $\mathrm{Al}_{2} \mathrm{O}_{3}$ 样品均分别在 $2 \theta=0.8^{\circ}$ 和 $1.5^{\circ}$ 附近出现一个较强和较弱的衍射峰, 分别对应着 (100) 和 (110) 晶面, 说明样品为有序的六方孔道结构; 而 $\mathrm{Co} / \mathrm{meso}^{-} \mathrm{Al}_{2} \mathrm{O}_{3}$ 催化剂的小角衍射峰完全消失, 说明 meso- $\mathrm{Al}_{2} \mathrm{O}_{3}$ 的介孔结构遭到破坏, 此与 $\mathrm{N}_{2}$ 吸脱附结果一致. 
由图 2(b) 可见, 浸渍法制备的 $\mathrm{Co} / \mathrm{meso}^{-} \mathrm{Al}_{2} \mathrm{O}_{3}$ 和 $\mathrm{Co} / \gamma-\mathrm{Al}_{2} \mathrm{O}_{3}$ 催化剂均出现很强的可归属于 $\mathrm{Co}_{3} \mathrm{O}_{4}$ 和/或 $\mathrm{CoAl}_{2} \mathrm{O}_{4}$ 物相的特征衍射峰; 而 Co-meso- $\mathrm{Al}_{2} \mathrm{O}_{3}$ 催化剂未 检出任何含 $\mathrm{Co}$ 物相, 说明 $\mathrm{Co}$ 物种高度分散. 还可以看 出, 在 $\mathrm{H}_{2}$ 中经 $800^{\circ} \mathrm{C}$ 还原 $2 \mathrm{~h}$ 后, 各催化剂上均出现金属 $\mathrm{Co}$ 的衍射峰, 但 Co-meso- $\mathrm{Al}_{2} \mathrm{O}_{3}$ 上峰强较弱、半峰宽较 大, 说明金属钴粒径较小.

图 3 为各还原催化剂的 TEM 照片和 Co-meso- $\mathrm{Al}_{2} \mathrm{O}_{3}$ 催化剂在其 TEM 照片所摄区域的 EDS 谱. 由图可见, $\mathrm{Co} / \gamma-\mathrm{Al}_{2} \mathrm{O}_{3}$ 和 $\mathrm{Co} / \mathrm{meso}-\mathrm{Al}_{2} \mathrm{O}_{3}$ 催化剂上均出现较大的金 属颗粒, 说明在高温还原过程中金属 Co 出现团聚. 经 $800^{\circ} \mathrm{C}$ 高温还原后的 Co-meso- $\mathrm{Al}_{2} \mathrm{O}_{3}$ 催化剂, 依然保持规 整的六方孔道结构, 且很难观察到团聚的颗粒, 而 EDS 谱发现有很强的 Co 元素信号. 结合 XRD 结果推知, 金属 Co 以粒径很小的颗粒高度分散于载体孔道中.

图 4 为不同催化剂的 $\mathrm{H}_{2}$-TPR 谱. 由图可见, $\mathrm{Co} / \gamma-\mathrm{Al}_{2} \mathrm{O}_{3}$ 样品在 520 和 $730^{\circ} \mathrm{C}$ 出现还原峰, 分别归属为 与载体作用较弱的 $\mathrm{Co}_{3} \mathrm{O}_{4}$ 颗粒和分散在载体表面并与载 体作用较强的钴氧化物的还原 ${ }^{[13,14]}$. 其中第一个还原峰 面积较大, 说明 $\mathrm{Co}$ 物种分散度较差, 主要以 $\mathrm{Co}_{3} \mathrm{O}_{4}$ 晶相 存在. $\mathrm{Co} / \mathrm{meso}-\mathrm{Al}_{2} \mathrm{O}_{3}$ 和 Co-meso- $-\mathrm{Al}_{2} \mathrm{O}_{3}$ 催化剂均在 800 ${ }^{\circ} \mathrm{C}$ 以上出现还原峰, 可归属于 $\mathrm{CoAl}_{2} \mathrm{O}_{4}$ 的还原 ${ }^{[13]}$; 其中
$\mathrm{Co} / \mathrm{meso}^{-} \mathrm{Al}_{2} \mathrm{O}_{3}$ 样品在 $800{ }^{\circ} \mathrm{C}$ 以下出现多个还原峰, 说明 除 $\mathrm{CoAl}_{2} \mathrm{O}_{4}$ 外, $\mathrm{Co}$ 物种还以 $\mathrm{Co}_{3} \mathrm{O}_{4}$ 晶相和表面钴氧化物 等多种形态存在, 而 Co-meso- $\mathrm{Al}_{2} \mathrm{O}_{3}$ 只在 $700^{\circ} \mathrm{C}$ 附近出现 1 个归属于高分散表面钴氧化物的还原峰, 表明其 Co 物 种的分散度较高, 与 XRD 结果一致.

图 5(a) 为各催化剂上 POM 反应结果. 由图可见, 浸 渍法制备的催化剂在 Co 负载量为 3\% 9\% 时, 甲烷转化 率都很低; 而 Co-meso- $\mathrm{Al}_{2} \mathrm{O}_{3}$ 在 $\mathrm{Co}$ 负载量低至 $6 \%$ 时就 表现出很高的催化活性. Wang 等 ${ }^{[10]}$ 也发现 $\mathrm{Co} / \mathrm{Al}_{2} \mathrm{O}_{3}$ 催 化剂具有优良的 POM 反应性能, 但其 Co 负载量高达 24\%. 一般而言, 较高的金属负载量容易导致积炭, 因而 低载量、高性能的催化剂对 POM 反应更为有效. 图 5(b) 为各催化剂 $(\mathrm{Co}$ 负载量为 $9 \%)$ 上 $\mathrm{CH}_{4}$ 转化率和 $\mathrm{CO}$ 选择 性随反应时间的变化. 可以看出, 与 $\mathrm{Co} / \mathrm{meso}-\mathrm{Al}_{2} \mathrm{O}_{3}$ 和 $\mathrm{Co} / \gamma-\mathrm{Al}_{2} \mathrm{O}_{3}$ 相比, Co-meso- $\mathrm{Al}_{2} \mathrm{O}_{3}$ 表现出较高的催化活性 和优越的稳定性, 反应 $1000 \mathrm{~h}$ 甲烷转化率和 $\mathrm{CO}$ 选择性 未见明显降低.

综上所述, 采用一锅合成法可直接合成介孔氧化铝 负载钴催化剂. 与浸渍法相比, 一锅法制备的 Co-meso$\mathrm{Al}_{2} \mathrm{O}_{3}$ 催化剂的比表面积和孔体积较大, 有利于活性组 分分散, 而载体孔道的限域作用提高了金属的抗烧结能 力, 因此 POM 反应中表现出较高的催化活性和稳定性. 